\title{
Coplanar PCB 77 uptake kinetics in the sea star Asterias rubens and subsequent effects on reactive oxygen species (ROS) production and levels of cytochrome P450 immunopositive proteins (CYP1A-IPP)
}

\author{
B. Danis ${ }^{1, *}$, O. Cotret $^{2}$, J. L. Teyssiée ${ }^{2}$, S. W. Fowler ${ }^{2}$, M. Warnau ${ }^{2}$ \\ ${ }^{1}$ Laboratoire de Biologie marine (CP 160/15), Université Libre de Bruxelles, Avenue FD Roosevelt 50, 1050 Brussels, Belgium \\ ${ }^{2}$ International Atomic Energy Agency, Marine Environment Laboratory, 4 Quai Antoine Ier, 98000 Monaco
}

\begin{abstract}
The kinetic behaviour of a highly toxic PCB congener (IUPAC 77) was investigated in the sea star Asterias rubens (Linnaeus, 1758) experimentally exposed via sea water, sediments or food. Simultaneously, biological effects were assessed at the immune and subcellular levels, respectively, by measuring reactive oxygen species (ROS) production and cytochrome P450 immunopositive protein (CYP1A-IPP) expression. The results indicate that sea stars efficiently accumulate the contaminant and that most organs bioconcentrate the congener according to saturation kinetics. In contrast to what has been shown previously for the non-coplanar PCB Congener 153, biological effects induced during exposure to PCB 77 were pronounced, and affected essential functions of the sea star biology (viz. immune and cytochrome P450 systems). These findings stress the need to (1) obtain further information about similar congener-specific biological effects in this species and in other organisms in the natural environment, and (2) include, when possible, coplanar PCBs in the list of congeners to be measured in marine pollutant biomonitoring programmes.
\end{abstract}

KEY WORDS: Polychlorinated biphenyls · PCB $77 \cdot$ Bioaccumulation · Asterias rubens $\cdot$ Echinoderm • CYP1A-IPP $\cdot$ Reactive oxygen species $\cdot$ Immune system

\section{INTRODUCTION}

Polychlorinated biphenyls (PCBs) are a class of widespread stable and persistent contaminants which have been widely used in industrial applications, such as electrical and hydraulic equipment, plastics, lubricants, pesticides and flame retardants (Metcalfe 1994). PCBs include 209 congeners, which differ by the chlorine substitution on the biphenyl rings. These compounds are found in the environment (e.g. Metcalfe 1994, Schreitmüller et al. 1994, Bright et al. 1995, Wania \& Daly 2002), and due to their inherent chemical, physical and toxicological properties, bioaccumulation of these compounds in marine biota is of growing concern (Stebbing et al. 1992, OSPAR Com 2000). These compounds are readily accumulated by organisms (Fowler et al. 1978, Boese et al. 1996, Koponen et al. 1998), and are known to have deleterious effects on key biological processes including reproduction, development and immunity (Harding \& Addison 1986, Zabel et al. 1995, Chapman 1996, Krogenaes et al. 1998, Coteur et al. 2001).

From a toxicological point of view, some congeners appear to be more problematic than others; indeed, the non-ortho- and mono-ortho-chlorinated congeners can display planar configuration (c-PCBs). In vertebrates, the toxicity of $\mathrm{C}-\mathrm{PCBs}$ is produced through a receptormediated response involving the binding of the contaminant to the cytosolic aryl hydrocarbon (Ah) receptor followed by changes in gene expression (Kohn 1983, Shugart et al. 1992, Safe 1995, Hahn 1998, Nebert et al. 2000). Although it is not known whether c-PCB toxicity is similarly Ah receptor-triggered in non-vertebrate organisms, Ah receptor homologues have been found in a series of invertebrates, such as the nematode Coenorhabditis elegans (Hahn et al. 
1997, Powell-Coffman et al. 1998), the arthropod Drosophila melanogaster (Duncan et al. 1998) and, more recently, in several molluscs (Butler et al. 2001, Wiesner et al. 2001). C-PCBs are known to induce CYP1A which is the major enzyme responsible for the metabolic activation of promutagens and procarcinogens in vertebrates. However, not all the adverse biological effects of PCBs are attributable to this mechanism. In particular, there is an increasing body of evidence that many PCBs can act both as endocrine disrupters and immunosuppressants through more complex and diverse pathways such as alterations of kinases and phospholipases, disturbance of $\mathrm{Ca}^{2+}$ homeostasis, and modulation of gene expression (Chiu et al. 2000, Satar 2000, Arukwe 2001).

In assessing the impending risk in the marine environment caused by these contaminants, monitoring biological effects is a fundamental issue (Suter 1993). To reach this goal, biomarkers are precious tools as they offer early warning signals (den Besten 1998). A biomarker is a variation in a biological response (ranging from molecular to cellular and physiological responses) that can be related to exposure or to toxic effects of chemicals (Bayne et al. 1988, Peakall 1992). In an environmental context, biomarkers are sensitive indicators of the entrance of a toxicant in an organism, its distribution among organs and/or tissues, and its toxic effect on critical processes (e.g. McCarthy \& Shugart 1990).

The common NE Atlantic sea star Asterias rubens is considered a valuable test organism because of its key position in benthic ecosystems and, more particularly, in the 'seston-mussel-sea star' food chain (den Besten et al. 2001). In previous studies, it has been shown that the accumulation of PCB mixtures in this food chain can lead to adverse effects on the reproduction of the sea star (e.g. den Besten et al. 1989). The effects of such contaminants have been assessed at the subcellular level using biomarkers such as benzo[a]pyrene hydroxylase (BaPH) activity (den Besten et al. 1990, 1993, den Besten 1998) and hormone synthesis rate (den Besten et al. 1991). Furthermore, in vitro or in vivo exposure of sea stars to PCBs has been reported to affect DNA integrity, larval development and immune and detoxification systems (den Besten et al. 1990, 1991, 1993, Everaarts \& Sarkar 1995).

The aim of the present work was (1) to describe the accumulation and tissue-distribution of a coplanar PCB congener (International Union of Pure and Applied Chemistry, IUPA C 77) in the sea star Asterias rubens exposed via sea water, sediments or food pathways and (2), in parallel, to assess the induced biological effects at the immune and subcellular levels. Bioaccumulation kinetics were studied by means of a ${ }^{14} \mathrm{C}$-labelled congener. This method has been used in a previous study (Danis et al. 2003), and displays many advantages over conventional methods (viz. electron capture detector-gas chromatography [ECD-GC] or gas chromatography-mass spectrometry [GC-MS] detection methods) in that it allows working at low, realistic levels of contamination and with small organs of very low weight. Biological effects were assessed by measuring reactive oxygen species (ROS) production by immune cells (ROS production is one of the main defences against pathogen infestation in invertebrates; Chia \& Xing 1996) and CYP1A immunopositive protein (CYP1A-IPP) induction in pyloric caeca (viz. the sea star digestive and storage organs which are analogous to the liver of vertebrates or the digestive gland of molluscs). Both effects are related, as disturbances of the catalytic cycle of CYP can lead to the production of ROS (Stegeman et al. 1992, Stegeman \& Hahn 1994).

\section{MATERIALS AND METHODS}

Sampling. Sea stars Asterias rubens (Linnaeus, 1758), were collected in April 2002 in the intertidal zone at Audresselles (Pas-de-Calais, France). Prior to experimentation, 250 specimens of similar size (5 to $7 \mathrm{~cm}$ arm radius) and weight ( $36 \pm 3.5 \mathrm{~g})$ were acclimated to laboratory conditions for 1 mo (constantly aerated opencircuit aquaria, $34 \mathrm{psu}, 16 \pm 0.5^{\circ} \mathrm{C}, 12 / 12 \mathrm{~h}$ dark/light cycle). Mussels Mytilus galloprovincialis were collected off 'la Pointe des Douaniers' (Cap d'Ail, France), and all specimens were held under similar controlled laboratory conditions until used in experiments.

Radiotracer. The ${ }^{14} \mathrm{C}$-labelled 3, 3',4,4' tetrachlorobiphenyl (purity $\geq 95 \%$ ) was purchased from Sigma Chemicals, USA. Specific activity was $25 \mathrm{MBq} \mathrm{mmol}^{-1}$. Stock solutions were prepared in acetone at a concentration of $1 \mu \mathrm{g} \mathrm{ml}^{-1}$.

Sample treatment and liquid scintillation counting. Water samples $(2 \mathrm{ml})$ were directly transferred to $20 \mathrm{ml}$ glass scintillation vials (Packard, USA) and $10 \mathrm{ml}$ of Ultima Gold $\mathrm{XR}^{\circledR}$ (Packard Instruments) scintillation liquid were added. Samples of sediment, mussel or sea star tissues (previously ground) were placed in a vial containing $2 \mathrm{ml}$ of Acetonitrile ${ }^{\circledR}$ in an ultrasonic bath for $10 \mathrm{~min}$. The Acetonitrile ${ }^{\circledR}$ was then collected and replaced by another $2 \mathrm{ml}$ of Acetonitrile ${ }^{\circledR}$ and the ultrasonic operation was repeated a second time. This treatment gave $4 \mathrm{ml}$ of liquid phase (viz. the extract) and a residue. The residue was digested overnight at $70^{\circ} \mathrm{C}$ with $2 \mathrm{ml}$ of Soluene ${ }^{\circledR}$, followed by an addition of $10 \mathrm{ml}$ of Hionic Fluor ${ }^{\circledR}$ scintillation liquid. The liquid phase (4 ml) was added to $16 \mathrm{ml}$ of filtered sea water and extracted twice using $2 \mathrm{ml}$ of $\mathrm{n}$-hexane (Sigma, USA) under constant agitation. The organic phase $(4 \mathrm{ml})$ and aqueous phase $(20 \mathrm{ml})$ were treated separately; the 
entire organic phase and $2 \mathrm{ml}$ of the aqueous phase were each added separately to $10 \mathrm{ml}$ of Ultima Gold $\mathrm{XR}^{\circledR}$ scintillation liquid.

${ }^{14} \mathrm{C}$-radioactivity was then measured using a $1600 \mathrm{TR}$ liquid scintillation analyser (Packard), compared to standards of known activities, and corrected for quenching, background and physical decay of the radiotracer. Counting times were adjusted to obtain counting rates with relative propagated errors less than $5 \%$. PCB concentrations were expressed on a total lipid-content basis, with lipids determined gravimetrically (UNEP 1990). A schematic diagram of the sample treatment is shown in Fig. 1.

Experimental procedures. Uptake from seawater: Sea stars $(n=25)$ were placed for $15 \mathrm{~d}$ in a $70 \mathrm{l}$ glass aquarium (constantly aerated closed-circuit aquaria; $34 \mathrm{psu} ; 16 \pm 0.5^{\circ} \mathrm{C} ; 12 / 12 \mathrm{~h}$ dark/light cycle) containing natural sea water spiked with ${ }^{14} \mathrm{C}$-labelled PCB 77 (nominal concentration $18 \mathrm{ng} \mathrm{l}^{-1}$ ), and $1 \mathrm{~d}$ prior to the experiments, four 51 glass beakers were filled with filtered sea water (34 psu; $\left.16 \pm 0.5^{\circ} \mathrm{C}\right)$, spiked with the radiolabelled $\mathrm{PCB}$ stock solution, and constantly stirred using an orbital agitation plate. Spiked water was then poured into the glass aquarium and natural sea water was added to obtain a final volume of $70 \mathrm{l}$. Sea water and radiotracer were renewed every second day during the entire experiment. Activity was checked before and after each renewal to assess the stability of the labelled PCB concentration in sea water. The sea stars were fed unlabelled mussels Mytilus galloprovincialis every second day just before the sea water renewal. After $2 \mathrm{~h}$, uningested mussels were removed to limit as much as possible PCB incorporation via the food (PCB measurements in uningested mussel soft parts were always below detection limit). Periodically, sea stars $(n=3)$ were removed, dissected into 6 body compartments (oral body wall, aboral body wall, pyloric caeca, gonads, rectal caeca and central digestive system), and radioanalysed to determine uptake kinetics.

Uptake from sediments: Sediments (2.5 kg dry wt) from the North Sea (Audresselles, Pas-de-Calais, France) were contaminated for $4 \mathrm{~d}$ with the ${ }^{14} \mathrm{C}$ labelled PCB using the rolling jar method (Murdoch et al. 1997). Sea stars $(n=60)$ were placed for $34 \mathrm{~d}$ in a $70 \mathrm{l}$ glass aquarium (constantly aerated open-circuit aquarium; flow $30 \mathrm{l} \mathrm{h}^{-1} ; 34 \mathrm{psu}_{;} 16 \pm 0.5^{\circ} \mathrm{C}_{;} 12 / 12 \mathrm{~h}$ dark/light cycle) containing a $10 \mathrm{~cm}$ layer of sea water running over a $2 \mathrm{~cm}$ layer of spiked sediments. A separate group of 5 sea stars were placed in the same aquaria, but in another compartment (not in contact with the sediments), to serve as a control for possible cross-contamination from labelled PCB in sea water. The sea stars were fed every second day with fresh mussels and any uningested food was removed after
$2 \mathrm{~h}$ (PCB measurements in uningested mussel soft parts were always below detection limit). The radioactivity of the labelled PCB was measured weekly in the sediments to check for possible leaching. Periodically, 3 individuals were removed, dissected as described above, and their tissues counted for radioactivity.

Uptake from food: Before the feeding experiment, mussels were exposed for $2 \mathrm{~d}$ in a glass aquarium containing $4 \mathrm{l}$ of filtrated sea water spiked with $18 \mathrm{ng} \mathrm{l}^{-1}$ PCB 77. Radiolabelled sea water was changed daily and mussels were regularly fed with the phytoplankter Isochrysis galbana. After $2 \mathrm{~d}$ exposure to the ${ }^{14} \mathrm{C}-\mathrm{PCB}$ congener, mussels were fed to the sea stars. Mussel exposure was carried out daily to obtain each day food that had been radiolabelled for $2 \mathrm{~d}$. We placed 60 sea stars for $34 \mathrm{~d}$ in a $70 \mathrm{l}$ glass aquarium (constantly aerated open-circuit aquarium; flow $30 \mathrm{l} \mathrm{h}^{-1}$; $34 \mathrm{psu}_{\text {; }}$

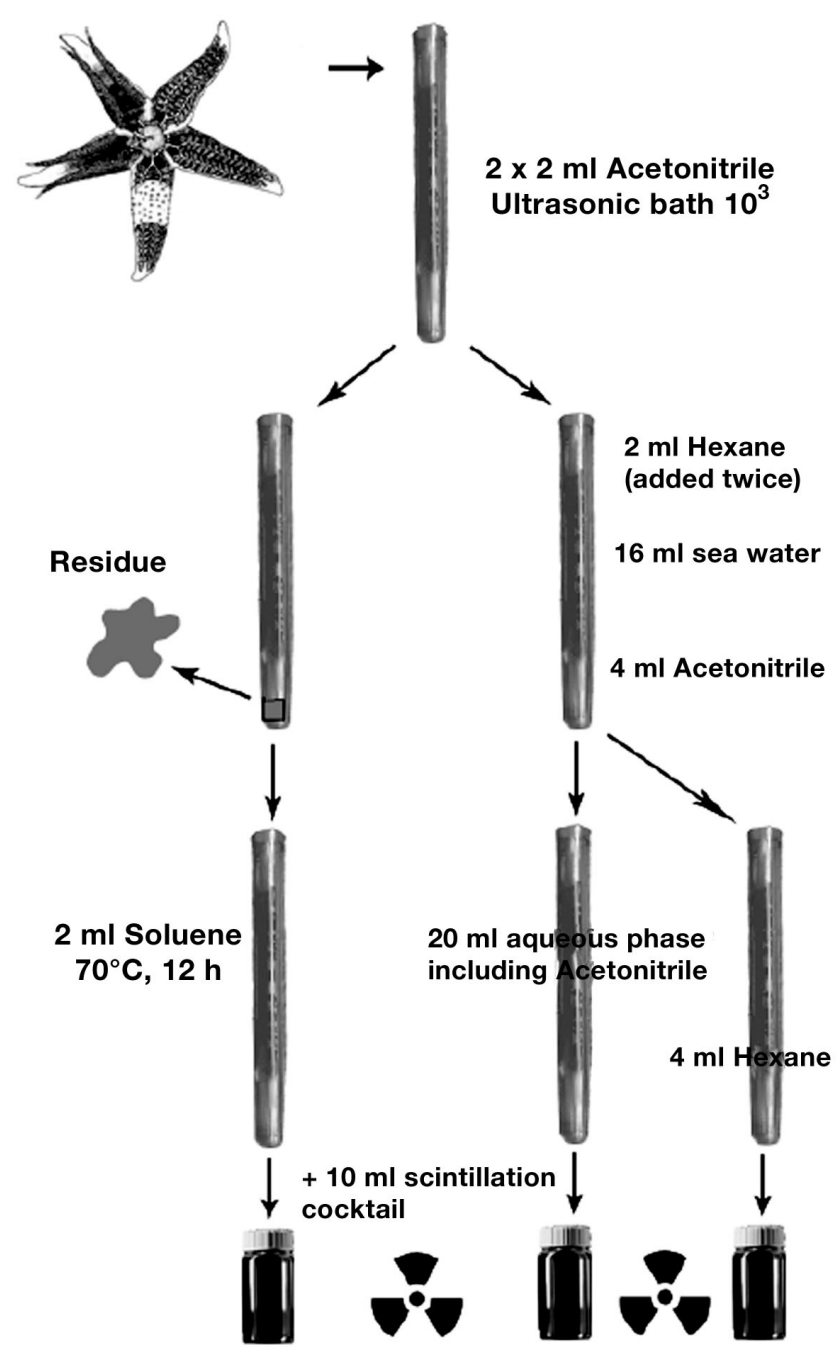

Liquid scintillation counting

Fig. 1. Schematic representation of sample processing before liquid scintillation counting 
$16 \pm 0.5^{\circ} \mathrm{C}_{i} 12 / 12 \mathrm{~h}$ dark/light cycle). Sea stars were allowed to feed daily for $1 \mathrm{~h}$ on radiolabelled mussels (1 mussel per sea star), and individuals were then periodically sampled to measure PCB uptake kinetics.

Reactive oxygen species (ROS) production measurements. ROS production by coelomocytes was measured by the peroxidase, luminol-enhanced method optimised by Coteur et al. (2001). Briefly, $3 \mathrm{ml}$ of coelomic fluid were collected in the same volume of anticoagulant buffer. The cell concentration was measured by absorbance at $280 \mathrm{~nm}$ using a Tecan Spectrafluor Plus plate-reader. This suspension was then centrifuged for $10 \mathrm{~min}$ at $400 \mathrm{~g}$ and resuspended in $\mathrm{Ca}^{2+}{ }_{-}, \mathrm{Mg}^{2+}$-free artificial sea water (ASW), the volume of which was adjusted to obtain a final amoebocyte concentration of $10^{6}$ cells $\mathrm{ml}^{-1}$. A stock solution of luminol and horseradish peroxidase (HRP) in DMSO was freshly diluted 100-fold in ASW (final concentrations of HRP and luminol were 500 and $250 \mu \mathrm{g} \mathrm{ml}^{-1}$, respectively). The reaction was begun by adding $200 \mu \mathrm{l}$ of amoebocyte suspension in $100 \mu \mathrm{l}$ of luminol/HRP solution, and $20 \mu \mathrm{l}$ of a Micrococcus luteus suspension containing $2.5 \times 10^{9}$ bacteria $\mathrm{ml}^{-1}$ (stimulated amoebocytes) or $20 \mu \mathrm{l}$ of ASW (non-stimulated amoebocytes). The chemiluminescence was measured every 10 min-over a $2 \mathrm{~h}$ period using a Tecan Spectrafluor Plus plate-reader placed in an incubator thermostabilised at $14 \pm 0.5^{\circ} \mathrm{C}$. Results were expressed as the sum of all 10 min interval measurements for $10^{6}$ cells $\mathrm{ml}^{-1}$ (total chemiluminescence) of bacteriastimulated amoebocytes or non-stimulated amoebocytes.

Cytochrome P450 immunopositive protein (CYP1AIPP) quantification. CYP1A-IPP content was quantified using a competitive-ELISA method which has been fully described elsewhere (Danis et al. 2004). Briefly, ELISA was carried out using competition between the CYP1A-IPP contained in the pyloric caeca of PCB-exposed sea stars and a biotinylated CYP1A from $\beta$-naphtoflavone (BNF)-injected trout Oncorhynchus mykiss. Multiwell plates (96 wells) were coated with Anti-CYP1A (rabbit anti-fish CYP1A peptide, polyclonal antibody; Biosense, Norway). Wells were washed with phosphate-buffered saline (PBS), and non-specific binding sites were blocked with PBSbovine serum albumin (BSA). Wells were washed again and biotinylated microsomes of BNF-injected trout were added (except for the blank wells). Sea star samples or standards (with protein concentration adjusted to $100 \mu \mathrm{g} \mathrm{ml}^{-1}$ ) were then added to the wells. Competition was allowed to take place for $2 \mathrm{~h}$, and after 5 washing steps extravidin-HRP was added to all the wells. The plates were then incubated for $45 \mathrm{~min}$ and the wells washed again using PBS. Chromogen TMB (Biosource, UK) was added to all the wells and the plates were incubated in the dark for $10 \mathrm{~min}$. Sulfuric acid was then added to stop the reaction and absorbance was measured at $450 \mathrm{~nm}$ using a microplate reader (Packard, Spectracount). Final results were expressed as induction factors, viz. the ratio of CYP1AIPP levels between experimental and control groups.

Data analyses. Uptake of the PCB congener from sea water, sediments or food was expressed as change in PCB concentration (ng $\mathrm{g}^{-1}$ total lipids) over time. Uptake kinetics were described either by using a saturation exponential model (Eq. 1), or a linear model (Eq. 2):

$$
\begin{gathered}
C(t)=C S S\left(1-\mathrm{e}^{-k_{\mathrm{e}} \times t}\right) \\
C(t)=k_{\mathrm{u}} \times t
\end{gathered}
$$

where $C(t)$ and Css are PCB concentrations (ng $\mathrm{g}^{-1}$ total lipids) at time $t(\mathrm{~d})$ and steady state, respectively, and $k_{\mathrm{u}}$ and $k_{\mathrm{e}}$ are the biological uptake and depuration rate constants $\left(\mathrm{d}^{-1}\right)$, respectively (Whicker \& Schultz 1982). The model showing the most accurate fit (based on calculation of the determination coefficient $\mathrm{R}^{2}$ and examination of the residuals) was selected.

Constants of the models and their statistics were estimated by iterative adjustment of the models and Hessian matrix computation, respectively, using the nonlinear curve-fitting routines in the Systat ${ }^{\circledR}$ 5.2.1 software (Wilkinson 1988). Differences among PCB concentrations in the different sea star body compartments and between ROS production and CYP1A-IPP levels in the different exposure conditions were tested by 1-way ANOVA and the multiple comparison test of Tukey (Zar 1996). Dose-response relationships were tested using linear and non-linear regressions. The level of significance for statistical tests was always set at $\alpha=0.05$.

\section{RESULTS}

\section{Uptake from sea water}

Regular monitoring of radiotracer activities in sea water allowed calculation of the time-integrated dissolved concentration of PCB 77; its value was $12.9 \pm$ $0.45 \mathrm{ng} \mathrm{l}^{-1}$. Uptake of the contaminant in the different body compartments displayed saturation kinetics, except in the gonads, in which the PCB was linearly accumulated (Fig. 2, Table 1). During the experiment (15 d), the digestive organs (viz. pyloric and rectal caeca and central digestive system) reached saturation, while saturation was almost reached in the oral and aboral body walls.

In order of decreasing bioaccumulation efficiency (Fig. 2, Table 2), the PCB 77 concentrations at the end of the exposure period were $286 \pm 89.7 \mathrm{ng} \mathrm{g}^{-1}$ lipids in the gonads, $262 \pm 55.2$ in the rectal caeca, $240 \pm 32.5$ in the oral body wall, $157 \pm 26.1$ in the aboral body wall, $53.1 \pm 7.14$ in the pyloric caeca and $11.9 \pm 3.05$ in the central digestive system. 
Table 1. Asterias rubens. Parameters and statistics of equations describing uptake of ${ }^{14} \mathrm{C}$-PCB 77 by different body compartments. L (linear model): $C(t)=k t$; S (saturation model): $C(t)=C S S\left(1-\mathrm{e}^{-k t}\right)$; where $C(t)$ and $C s S={ }^{14} \mathrm{C}-\mathrm{PCB} 77$ concentrations ( $\mathrm{ng} \mathrm{g}^{-1}$ lipids) at time $t$ (d) and at steady-state, respectively; $k=$ rate constant $\left(\mathrm{d}^{-1}\right)$. ASE: asymptotic standard error; $\mathrm{R}^{2}$ : corrected determination coefficient

\begin{tabular}{|lrrrr|}
\hline Body compartment & Model & CSS (ASE) & $k$ (ASE) & $\mathrm{R}^{2}$ \\
\hline Sea water exposure & & & & \\
$\quad$ Oral body wall & $\mathrm{S}$ & $326(53.3)$ & $0.11(0.03)$ & 0.84 \\
Aboral body wall & $\mathrm{S}$ & $190(22.9)$ & $0.14(0.03)$ & 0.84 \\
Gonads & $\mathrm{L}$ & & $19.2(2.21)$ & 0.53 \\
Pyloric caeca & $\mathrm{S}$ & $52(3.30)$ & $0.77(0.20)$ & 0.37 \\
Rectal caeca & $\mathrm{S}$ & $289(18.7)$ & $0.32(0.06)$ & 0.72 \\
Central digestive system & $\mathrm{S}$ & $13.0(0.95)$ & $0.47(0.13)$ & 0.53 \\
Sediments exposure & & & & \\
Oral body wall & $\mathrm{S}$ & $125(32.3)$ & $0.05(0.02)$ & 0.59 \\
Aboral body wall & $\mathrm{S}$ & $194(14.9)$ & $0.22(0.05)$ & 0.62 \\
Gonads & $\mathrm{S}$ & $256(67.6)$ & $0.04(0.02)$ & 0.80 \\
Pyloric caeca & $\mathrm{S}$ & $109(7.09)$ & $0.17(0.03)$ & 0.78 \\
Rectal caeca & $\mathrm{S}$ & $300(11.5)$ & $0.11(0.01)$ & 0.95 \\
Central digestive system & $\mathrm{S}$ & $11.7(0.82)$ & $0.37(0.11)$ & 0.57 \\
Food exposure & & & & \\
Oral body wall & $\mathrm{S}$ & $76.7(5.65)$ & $0.16(0.04)$ & 0.72 \\
Aboral body wall & $\mathrm{S}$ & $195(18.2)$ & $0.09(0.02)$ & 0.82 \\
Gonads & $\mathrm{L}$ & & $4.85(0.34)$ & 0.67 \\
Pyloric caeca & $\mathrm{S}$ & $141(6.31)$ & $0.14(0.02)$ & 0.89 \\
Rectal caeca & $\mathrm{S}$ & $190(11.7)$ & $0.16(0.03)$ & 0.77 \\
Central digestive system & $\mathrm{S}$ & $43.1(2.84)$ & $0.16(0.03)$ & 0.76 \\
\hline
\end{tabular}

Correlations, calculated between PCB 77 concentrations measured in the different body compartments, showed that concentrations in the oral body wall were significantly correlated to those in the aboral body wall ( $\mathrm{r}=0.68$; Fig. 3), gonads ( $r=0.50)$, rectal caeca $(\mathrm{r}=0.37)$ and central digestive system $(r=0.29)$. Significant correlation was also found between PCB 77 concentrations measured in the aboral body wall and those measured in the rectal caeca $(\mathrm{r}=0.50)$ and gonads $(\mathrm{r}=0.43)$.

\section{Uptake from sediments}

Regular monitoring of radiotracer activities in the sediment revealed no significant change of the PCB 77 concentration during the experiment, and the time-integrated concentration was $16.1 \pm 10.7 \mathrm{ng} \mathrm{g}^{-1}$ dry wt. Uptake of PCB 77 by sea stars displayed saturation kinetics for all body compartments (Fig. 4, Table 1). The concentrations
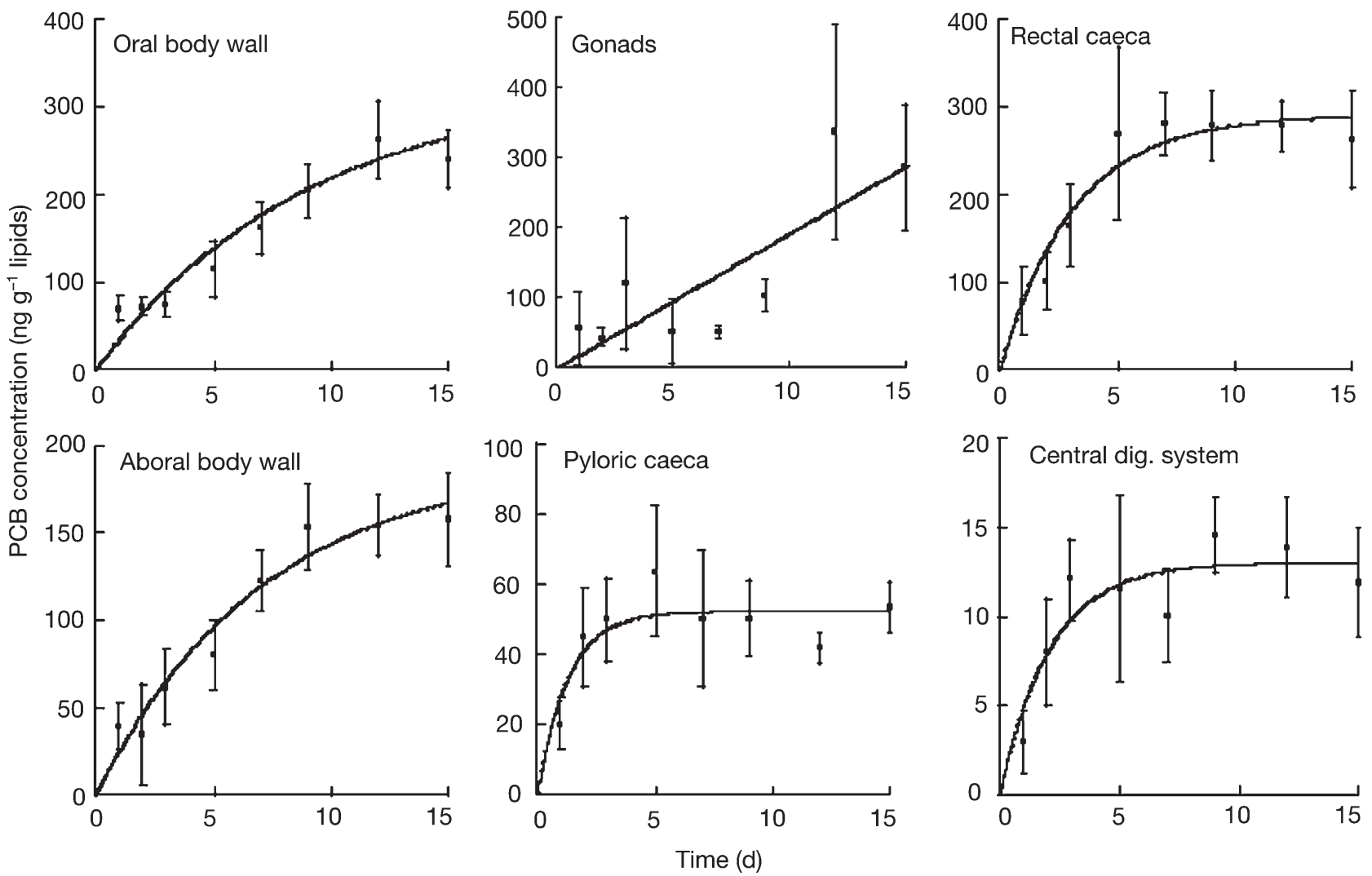

Fig. 2. Asterias rubens. Mean $\left( \pm \mathrm{SD} ; \mathrm{n}=3\right.$ ) uptake $\left(\mathrm{ng} \mathrm{g}{ }^{-1}\right.$ total lipids) of ${ }^{14} \mathrm{C}$-PCB 77 from sea water by different body compartments 
Table 2. Asterias rubens. Concentration factors (CF) and transfer factors (TF) (mean $\pm \mathrm{SD} ; \mathrm{n}=24$ for sea water exposure and $\mathrm{n}=33$ for sediments and food exposures) in body compartments at end of exposure via sea water, sediments or food. CFs calculated as ratio between PCB 77 concentration in body compartments (ng - $^{-1}$ total lipids) and its concentration in sea water (ng $\mathrm{g}^{-1}$ ), TFs calculated as ratio between PCB 77 concentration in body compartments (ng g ${ }^{-1}$ total lipids) and concentration in sediments (ng $\mathrm{g}^{-1}$ dry wt) or in food (ng g ${ }^{-1}$ total lipids). BW: body wall, Pyl. Caec.: pyloric caeca, Rect. Caec.: rectal caeca, CDS: central digestive system

\begin{tabular}{|lcccccc|}
\hline Experiment & Oral BW & Aboral BW & Gonads & Pyl. caec. & Rect. caec. & CDS \\
\hline Sea water (CF) & $18.600 \pm 2520$ & $12.200 \pm 2020$ & $22.100 \pm 6950$ & $4.110 \pm 550$ & $20.300 \pm 4280$ & $920 \pm 237$ \\
Sediments (TF) & $8.31 \pm 1.74$ & $14.1 \pm 3.80$ & $11.9 \pm 1.80$ & $7.37 \pm 2.20$ & $21.5 \pm 2.06$ & $0.97 \pm 0.35$ \\
Food (TF) & $2.84 \pm 1.30$ & $7.93 \pm 2.03$ & $5.90 \pm 1.12$ & $5.26 \pm 0.73$ & $6.16 \pm 1.18$ & $1.51 \pm 0.22$ \\
& & & & & \\
\hline
\end{tabular}

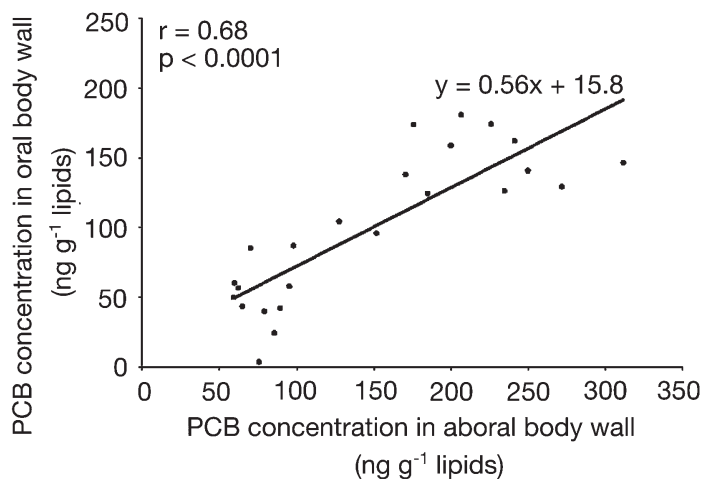

Fig. 3. Asterias rubens. Linear regression between ${ }^{14} \mathrm{C}-\mathrm{PCB}$ 77 concentration (ng $\mathrm{g}^{-1}$ total lipids) in oral and aboral body walls of sea stars exposed to contaminated sea water for 15 d. r: correlation coefficient reached at the end of the exposure period ranged from $13.3 \pm 4.78 \mathrm{ng} \mathrm{g}^{-1}$ lipids in the central digestive system to $295 \pm 28.2 \mathrm{ng} \mathrm{g}^{-1}$ lipids in the rectal caeca.

The estimated mean transfer factors (TFs) indicated that bioaccumulation in the body compartments was ranked differently than in the case of sea waterexposed sea stars (Table 2), with the rectal caeca showing the highest TF, followed by the aboral body wall and gonads. In addition, TF values were 3 orders of magnitude lower than the concentration factors (CFs) calculated in the sea water experiment in which sea stars were exposed for only half the time.

Significant correlations were calculated between PCB concentrations measured in the different body compartments at the end of the exposure period; the strongest one was found for pyloric versus rectal caeca
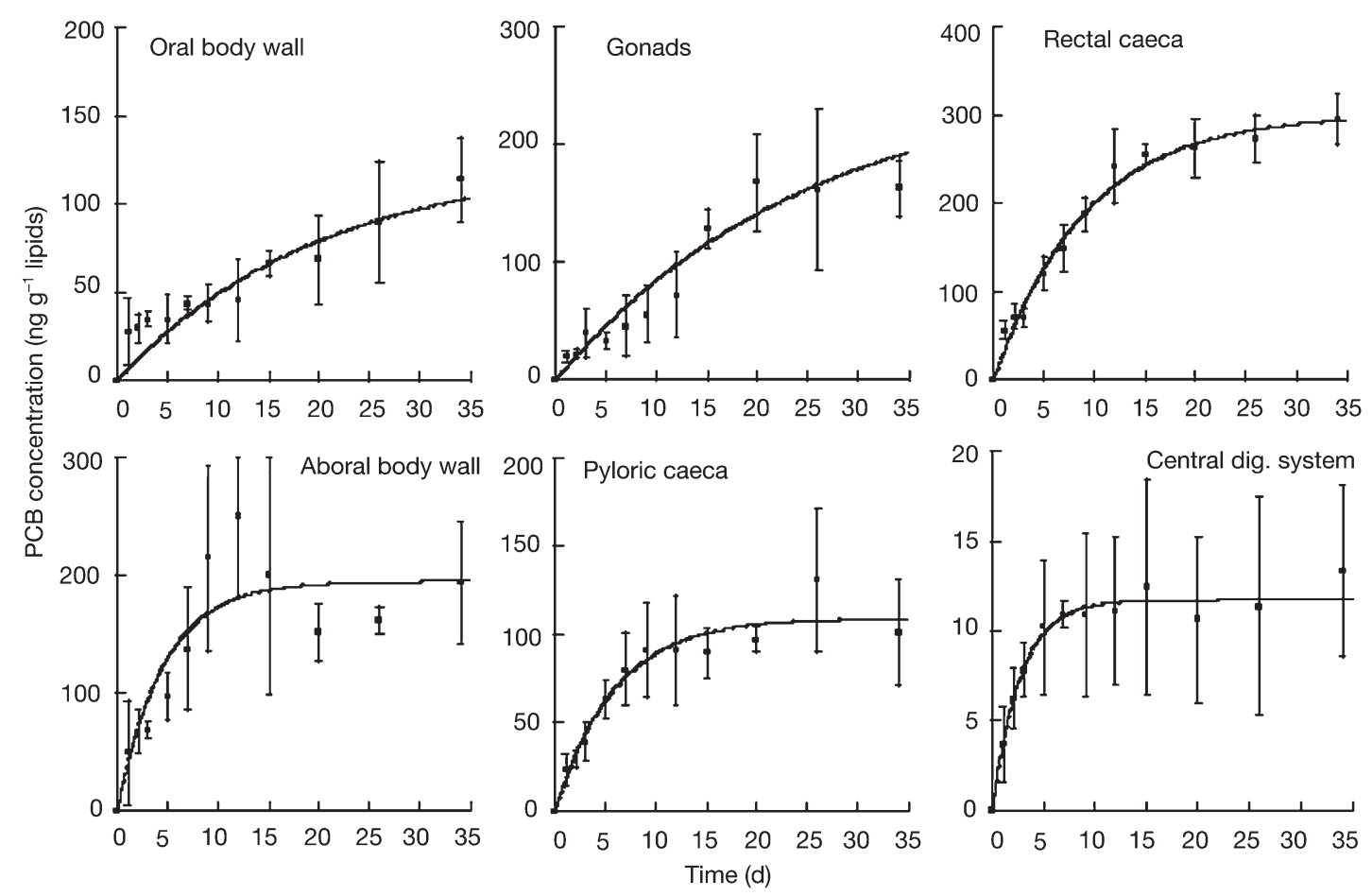

Fig. 4. Asterias rubens. Mean $\left( \pm \mathrm{SD}_{;} \mathrm{n}=3\right)$ uptake $\left(\mathrm{ng} \mathrm{g}^{-1}\right.$ total lipids) of ${ }^{14} \mathrm{C}$-PCB 77 from sediments in different body compartments 


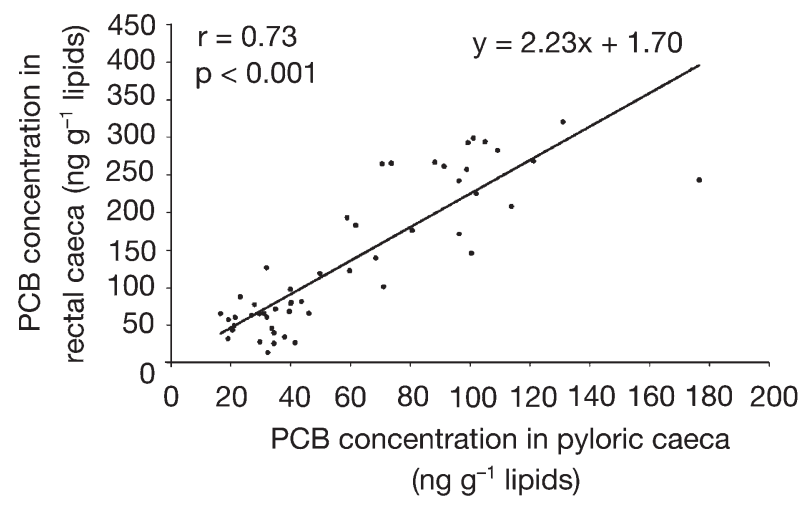

Fig. 5. Asterias rubens. Linear regression between ${ }^{14} \mathrm{C}$-PCB 77 concentrations (ng $\mathrm{g}^{-1}$ total lipids) in rectal and pyloric caeca of sea stars exposed to contaminated sediment for $34 \mathrm{~d}$

$(\mathrm{r}=0.73$; Fig. 5), followed by weaker correlations for gonads versus oral body wall $(\mathrm{r}=0.51)$, and aboral body wall versus rectal caeca $(r=0.34)$.

\section{Uptake from food}

Except for the gonads, uptake of PCB 77 by the body compartments of sea stars fed contaminated mussels displayed saturation kinetics (Fig. 6, Table 1). PCB 77 uptake in gonads was best fitted using a linear model.
The concentrations measured after $34 \mathrm{~d}$ exposure ranged from $39.9 \pm 5.88 \mathrm{ng} \mathrm{g}^{-1}$ lipids in the central digestive system to $210 \pm 53.7 \mathrm{ng} \mathrm{g}^{-1}$ lipids in the aboral body wall (Fig. 6).

TFs from food were of the same order of magnitude as those calculated for sediment-exposed sea stars; they reached a maximum of 7.93 in the aboral body wall after $34 \mathrm{~d}$ exposure (Table 2).

Correlations were found between PCB concentrations measured in the different body compartments at the end of the feeding period. The highest correlation was found between the pyloric and the rectal caeca $(\mathrm{r}=0.67$; Fig. 7).

\section{ROS production}

Reactive oxygen species (ROS) production was measured in amoebocytes collected from the sea stars sampled during the sea water, sediments and or food experiments; these results are presented in Fig. 8. In the case of sea water-exposed sea stars, the measurement of ROS production in non-stimulated amoebocytes showed no clear trends. However, bacteriastimulated amoebocytes were induced to produce more ROS during the first $5 \mathrm{~d}$, whereafter ROS production decreased again to control levels until the end of the experiment (Fig. 8a). During the sediment experi-
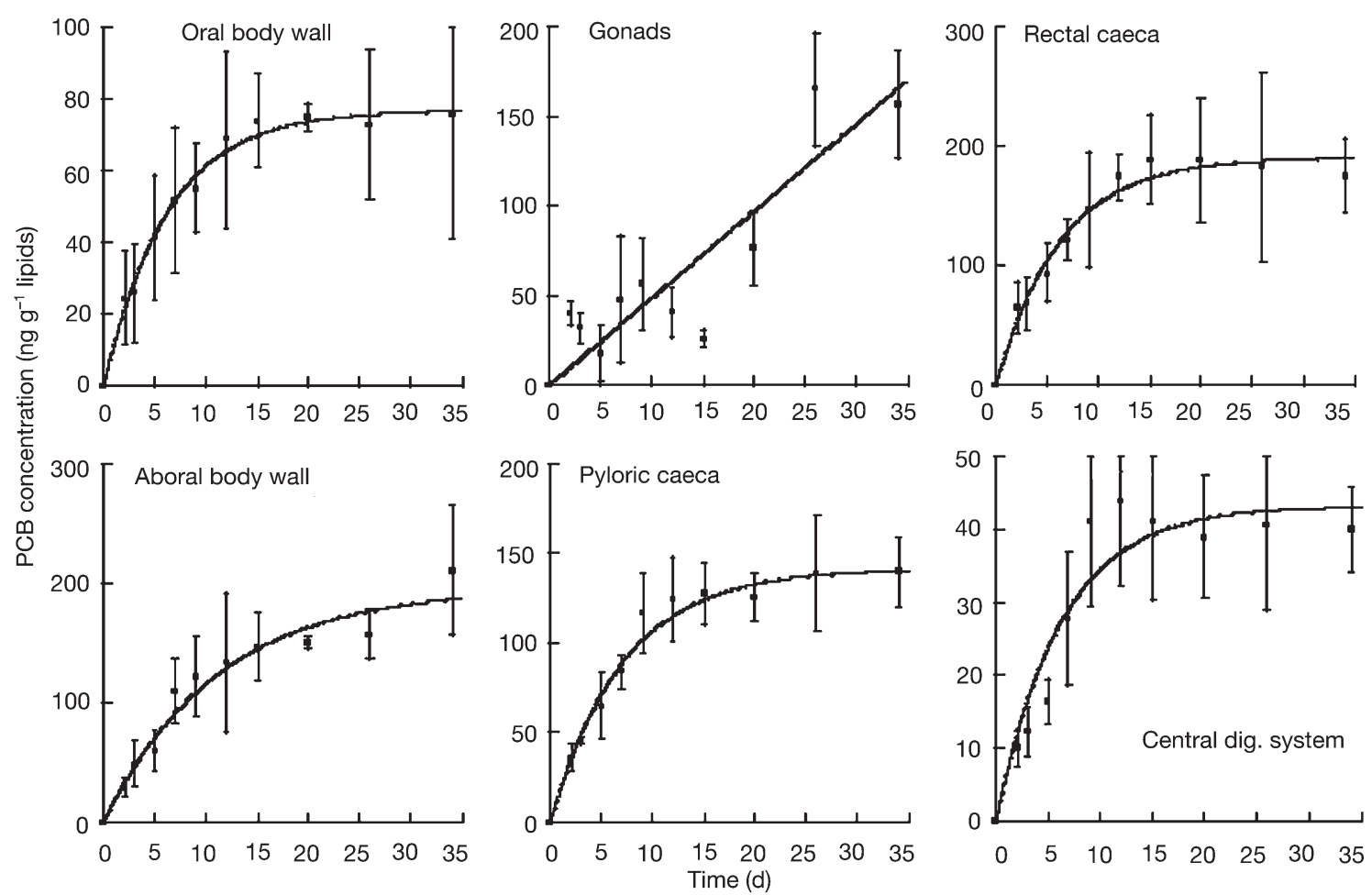

Fig. 6. Asterias rubens. Mean $\left( \pm \mathrm{SD}_{i} \mathrm{n}=3\right.$ ) uptake ( $\mathrm{ng} \mathrm{g}^{-1}$ total lipids) of ${ }^{14} \mathrm{C}-\mathrm{PCB} 77$ from food (Mytilus galloprovincialis) by different body compartments 


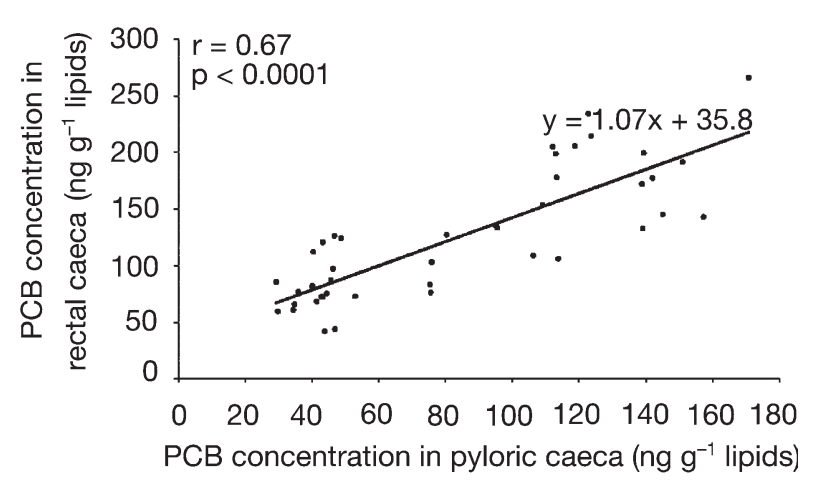

Fig. 7. Asterias rubens. Linear regression between ${ }^{14} \mathrm{C}$-PCB 77 concentrations (ng g ${ }^{-1}$ total lipids) in rectal and pyloric caeca of sea stars fed contaminated food for $34 \mathrm{~d}$
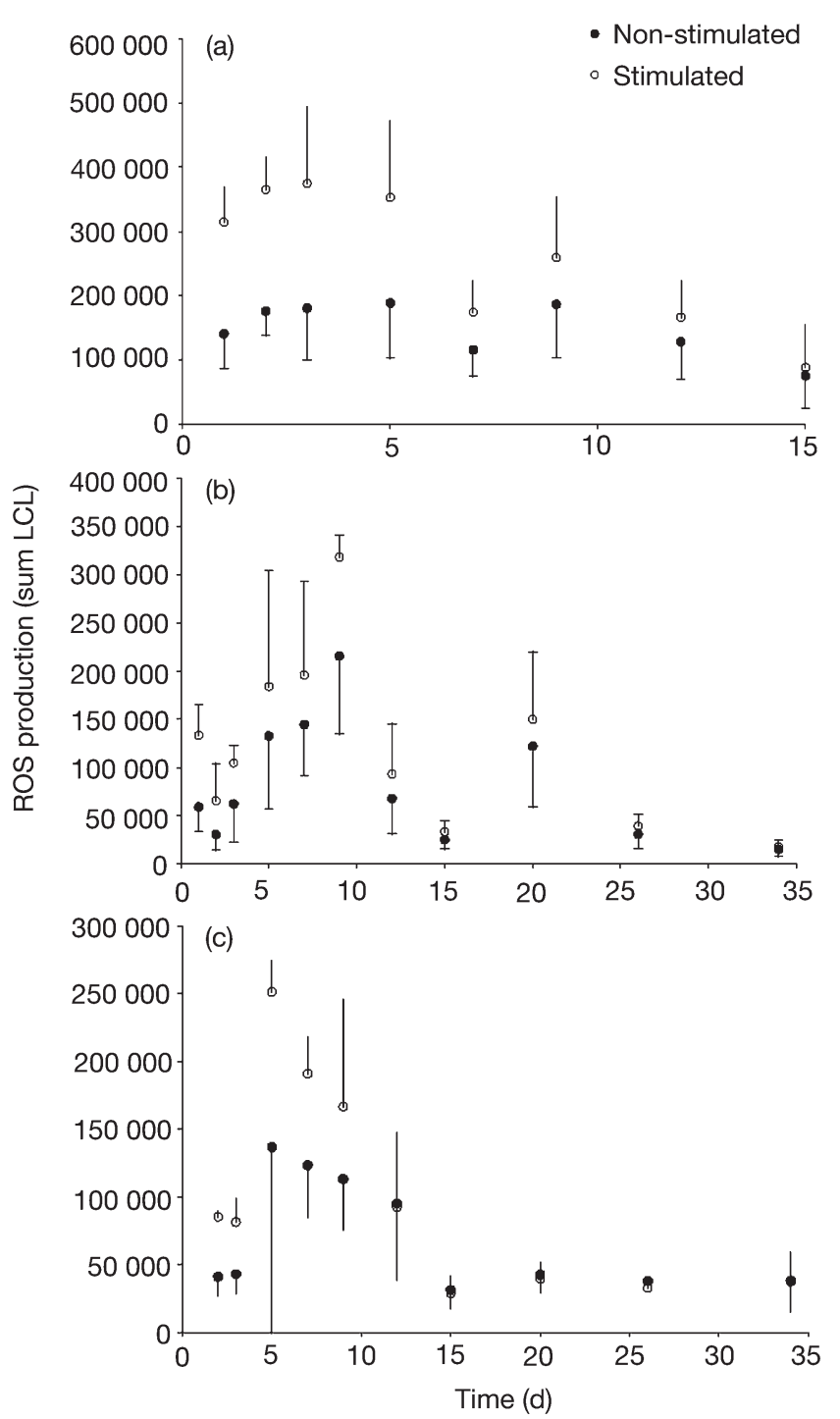

Fig. 8. Asterias rubens. Mean $\left( \pm \mathrm{SD}_{;} \mathrm{n}=3\right)$ reactive oxygen species (ROS) production; in sea stars exposed to ${ }^{14} \mathrm{C}-\mathrm{PCB} 77$ via (a) sea water, (b) sediment, or (c) food. sum LCL: nonstimulated and bacteria-stimulated amoebocytes ment (Fig. 8b), an increasing trend was observed during the first $9 \mathrm{~d}$ exposure, at which time ROS levels dropped dramatically. The same trends were also observed in amoebocytes from sea stars exposed to labelled food; in this experiment maximum ROS production was reached after $5 \mathrm{~d}$ exposure (Fig. 8c).

Correlations between non-stimulated and bacteriastimulated ROS production were found for all exposure routes, but with variable correlation coefficient values: $\mathrm{r}_{\text {seawater }}=0.72, \mathrm{r}_{\text {sediments }}=0.94, \mathrm{r}_{\text {food }}=0.50$.

\section{CYP1A immunopositive protein induction}

Cytochrome P450 (CYP1A) immunopositive protein (CYP1A-IPP) induction was measured in pyloric caeca collected from experimental sea stars exposed to PCB 77 via sea water, sediments and food (Fig. 9). Induction of CYP1A-IPP followed saturation kinetics whichever exposure route was considered (Table 3). Saturation values were higher in the case of sediments and food exposure, but the rate constant was almost 3 times faster in the case of sea water exposure.

For each exposure route, significant correlations were found between CYP1A-IPP induction and PCB concentrations measured in sea star body compartments. The highest correlations were found for the gonads $(r=0.55)$ during sediment exposure, the aboral body wall $(r=0.45)$ during sea water exposure, and the oral body wall $(r=0.29)$ during food exposure.

\section{DISCUSSION}

Although sea stars have been reported to concentrate PCBs efficiently, the available literature mainly concerns field measurements of these contaminants in the tissues and organs, and more specifically concerns

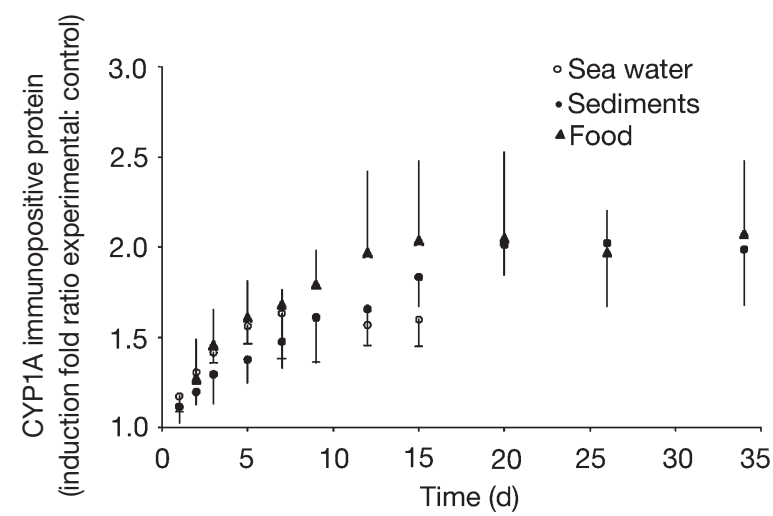

Fig. 9. Asterias rubens. Mean $\pm \mathrm{SD}(\mathrm{n}=3) \mathrm{CYP} 1 \mathrm{~A}$ IPP induction (ratio of experimental response to control group) using competitive ELISA for sea stars exposed to ${ }^{14} \mathrm{C}$-PCB 77 via sea water, sediment or food 
Table 3. Asterias rubens. Parameters and statistics of equations describing expression of CYP1A immunopositive protein during exposure experiments. Kinetics described using saturation model $C(t)=C s s\left(1-\mathrm{e}^{-\lambda t}\right)$, where $\lambda$ is the rate constant $\left(\mathrm{d}^{-1}\right)$. Other abbreviations as in Table 1

\begin{tabular}{|lccc|}
\hline Exposure route & CSS (ASE) & $\lambda(\mathrm{ASE})$ & $\mathrm{R}^{2}$ \\
\hline Sea water & $1.57(0.04)$ & $1.16(0.18)$ & 0.50 \\
Sediments & $1.91(0.06)$ & $0.40(0.09)$ & 0.42 \\
Food & $1.98(0.06)$ & $0.42(0.08)$ & 0.37 \\
\hline
\end{tabular}

non-coplanar congeners (e.g. Stebbing et al. 1992, Everaarts et al. 1998, den Besten et al. 2001, Stronkhorst et al. 2003). One previous experimental study focused on bioaccumulation kinetics of the noncoplanar congener 153 following exposure via sediments or sea water (Danis et al. 2003). To the best of our knowledge, no previous information is available regarding the relative importance of the different exposure routes on uptake of coplanar congeners in marine invertebrates.

In the present study, biokinetic experiments were performed using a ${ }^{14} \mathrm{C}$-labelled PCB coplanar congener (IUPAC 77). The procedure was designed in order to obtain experimental contaminant concentrations on the same order as those found in heavily contaminated marine environments (Bergen et al. 1996, Tolosa et al. 1997). In general, the coplanar PCB congener was readily accumulated by Asterias rubens exposed via sea water (CFs ranging from 672 to 22100 according to the body compartment after $15 \mathrm{~d}$ of exposure), via sediments (TFs ranging from 1 to 22 after $34 \mathrm{~d}$ of exposure) or via food (TFs ranging from 1.5 to 7.9 after $34 \mathrm{~d}$ of exposure). In a previous study using the non-coplanar congener PCB 153, maximum TFs and CFs were, respectively, up to 1 and 2 orders of magnitude higher than in the present study (Danis et al. 2003).

When considering CFs and TFs, the relative bioaccumulation efficiency was up to 3 orders of magnitude higher in seawater-exposed animals than when sea stars were exposed via sediments or food. The same observation was made for PCB 153 (Danis et al. 2003); i.e. in relation to exposure concentrations, PCB uptake was far more efficient in sea stars exposed to spiked sea water than in those exposed to labelled sediments. Therefore, over the long-term, despite the fact that sediments constitute the main reservoir of PCBs in the marine environment and that comparative sea water PCB concentrations are extremely low, sea water could be a non-negligible route for PCB bioaccumulation in the sea star, as has been suggested for other benthic infauna (e.g. Fowler et al. 1978). However, this does not imply that sea water would be the predominant pathway for PCB uptake, since our results show that final concentrations reached in the different body compartments following the 3 types of exposure were generally similar.

In contrast with observations of Danis et al. (2003) for PCB 153, concentrations of PCB 77 incorporated into the rectal caeca were in the same range as those measured in other tissue compartments. Although we do not have a clear explanation for this, it is nevertheless interesting, since PCB 153 concentrations in the rectal caeca were between 1 and 2 orders of magnitude lower than in all the other compartments.

In most body compartments, accumulation kinetics were described using saturation models. In sea waterexposed individuals, the highest saturation concentrations were reached in the gonads, rectal caeca and oral body wall, but the compartment reaching saturation at the fastest rate was the pyloric caeca. In sedimentexposed sea stars, rectal caeca displayed the highest saturation concentration, but the central digestive system had the highest PCB accumulation rate. Foodexposed individuals displayed the highest saturation concentrations in the rectal caeca and aboral body wall, and the different body compartments showed similar accumulation rates. In respect to the different accumulation routes, the highest uptake rates were found in sea water-exposed sea stars, followed by sediments and food, attesting to the importance of sea water as a PCB exposure pathway.

Particular concern arises from the PCB uptake of the gonads of the sea star. Relatively high concentrations were incorporated in these organs according to linear uptake kinetics, suggesting that a steady state in this compartment would take a very long time to be reached under natural conditions. This may have an important impact on sea star population survival, because of the endocrine disrupting effect of coplanar PCBs (den Besten et al. 1989, Suedel et al. 1997, Chiu et al. 2000).

In parallel to bioaccumulation kinetics, 2 different biological effects were measured: ROS production by amoebocytes and CYP1A immunopositive protein induction in pyloric caeca. Significant stimulation of ROS production by amoebocytes was observed in PCB 77-exposed sea stars regardless of the exposure pathway. In addition, ROS production stimulation was observed in bacteria-stimulated amoebocytes as well as in non-stimulated cells. This contrasts with the observations of Coteur et al. (2001), who did not observe any significant ROS production by non-stimulated coelomocytes of PCB 77-exposed sea urchins Paracentrotus lividus. This is most probably due to differences in the composition of the coelomocyte population between sea urchins and sea stars. Amoebocytes which are responsible for ROS production are the sole, 
free-circulating coelomocyte type in Asterias rubens, whereas there are 6 different coelomocyte types coexisting in sea urchins (Chia \& Xing 1996). As ROS production is measured on a 'per cell' basis, the difference in coelomocyte population composition could result in an underestimated response when ROS production is measured in sea urchins compared to the same response in Asterias rubens.

Surprisingly, after a strong stimulation during the first 4 to $10 \mathrm{~d}$, ROS production fell to control levels after a variable period of time. This could have been due to a toxic effect on the amoebocytes occurring when the PCB concentrations reached a certain level within the organism's tissues. This toxicity could impair or inhibit the ROS production capacity of the amoebocytes. It has been shown in both sea stars and sea urchins that when coplanar PCBs are injected into the coelomic cavity, ROS production is stimulated proportionally to the injected dose up to a certain injected concentration, after which it drops to control levels (Coteur et al. 2001, Danis et al. 2004). However, this hypothesis may not completely explain our results since the PCB concentrations incorporated by the sea stars were very similar during the first few days of exposure regardless of the exposure pathway (sea water, food or sediments), whereas the time at which ROS production began to decrease varied between Days 4 (sea water exposure) and 9 (sediment exposure).

Alternatively, the decrease in ROS production could be due to the progressive activation of an efficient detoxification mechanism (e.g. components of the cytochrome P450 system, CYP1A) that would limit and then eliminate the impact of PCB 77 on amoebocyte functions, and thus on the stimulation of these immune cells to produce ROS. Induction of P450 enzymatic activity has been reported in echinoderms exposed to coplanar PCB congeners (den Besten et al. 1993). In the present study, significant induction of CYP1A-IPP protein (one of the main proteins responsible for P450 enzymatic activity in vertebrates) was measured in the pyloric caeca of PCB 77-exposed sea stars, regardless of the exposure pathway, and CYP1A-IPP induction increased with time according to saturation kinetics.

It should be kept in mind that even if CYP1A-IPP is clearly induced in Asterias rubens, it does not necessarily imply that a corresponding enzymatic activity is similarly stimulated. Furthermore, the involvement of the P450 enzymatic system in C-PCB detoxification has not been demonstrated in invertebrate organisms. However, functional interpretation of our data suggests that CYP1A-IPP induction actually results in a detoxification mechanism that decreases PCB 77 effects on ROS production. Indeed, from Fig. 9 it is evident that at the time when ROS production reaches its maximum in sea stars exposed via sea water or food (i.e. Day 5), the CYP1A-IPP induction factor is identical (1.6) for both groups of sea stars. At the same time, this factor is lower in sediment-exposed individuals. Furthermore, the CYP1A-IPP induction factor reaches a similar value (1.6) in sediment-exposed sea stars at the same time as ROS production reaches its maximum value in the same group of sea stars. This suggests that CYP1A-IPP could have a CYP1A enzymatic activity and that the latter would reach effective efficiency at an induction factor of ca. 1.6 (under our experimental conditions), above which the action of PCB 77 on the immune system would be efficiently limited, resulting in more normal ROS production levels. This is of prime importance from a biological point of view, since our data suggest that exposure to low PCB 77 concentrations (viz. concentrations ineffective in inducing CYP1A-IPP) could result in dysfunctions of defences against infections (see e.g. Livingstone et al. 2000).

In conclusion, Asterias rubens efficiently took up the coplanar PCB Congener 77, which was distributed in all the tissues examined. Consequent biological effects were pronounced and affected essential sea star physiological functions at experimental PCB levels corresponding to concentrations encountered in heavily contaminated environments. Indeed, the present work showed that both ROS production (one of the main lines of defence against microorganism agression in invertebrates) and CYP1A-IPP levels were impacted. In this sea star species, exposed under the experimental conditions considered here, the immune effects appeared to be reversible. The ROS production parameter could thus be a very interesting short-term biomarker of the presence of coplanar PCBs, and probably of other dioxin-like organic contaminants as well. Furthermore, its use in conjunction with the increased expression of CYP1A-IPP would allow the gathering of highly informative data about the time-scales of exposure of animals, since this parameter has different stimulation kinetics than ROS production; i.e. the CYP1A signal is still observable in organisms when ROS production has returned to control levels.

At present, the recommendations related to $\mathrm{PCB}$ monitoring in the environment that are adopted by international organisations such as the European Union (EU) or International Council for the Exploration of the Sea (ICES), address a limited number of PCB congeners, viz. 28, 52, 101, 118, 138, 153 and 180. These congeners are well-known to be the most abundant in marine biota. They are also accurately detected and quantified, have good intercomparability value, and are fairly indicative of the presence of other PCBs (see e.g. Metcalfe 1994, OSPAR Commission 2000). However, these congeners are not at all indicative of PCB toxicity to marine invertebrates or of their potential threat to marine ecosystems. Indeed, an increasing 
data set for a variety of marine organisms demonstrates that coplanar congeners, even at very low concentrations, display TCDD (tetrachlorodibenzo- $p$ dioxin)-like PCB toxicity (e.g. Wilbrink et al. 1991, Michel et al. 1993, Schweitzer et al. 1997, den Besten 1998, Coteur et al. 2001, Duffy et al. 2002, Danis et al. 2004, and present study). These observations underscore the need to provide further information in natural marine environments about congener-specific biological effects, especially in the most commonly used bioindicator species (i.e. bivalves), in order to assess whether coplanar PCBs should be included in the list of congeners to be monitored in programmes using an integrated chemical and biological approach.

Acknowledgements. The IAEA Marine Environment Laboratory operates under a bipartite agreement between the International Atomic Energy Agency and the Government of the Principality of Monaco. B.D. is holder of an FRIA doctoral grant, and M.W. is an Honorary Research Associate of the National Fund for Scientific Research (NFSR, Belgium). The research was partly supported by a travel grant from the Belgian Ministry of the French Community to B.D. and by a NFSR equipment funding to M.W. (Tecan Spectrafluor Plus plate-reader).

\section{LITERATURE CITED}

Arukwe A (2001) Cellular and molecular responses to endocrine-modulators and the impact on fish reproduction. Mar Pollut Bull 42:643-655

Bayne BL, Clarke KR, Cray JS (1988) Biological effects of pollutants. Mar Ecol Prog Ser 46 (MEPS Special)

Bergen BJ, Nelson WG, Pruell RJ (1996) Comparison of nonplanar and coplanar PCB congener partitioning in sea water and bioaccumulation in blue mussels (Mytilus edulis). Environ Toxicol Chem 15:1517-1523

Boese BL, Specht DT, Pelletier J, Randall R (1996) Evaluation of PCB and hexachlorobenzene biota-sediment accumulation factors based on ingested sediment in a depositfeeding clam. Environ Toxicol Chem 15(9):1584-1589

Bright DA, Dushenko WT, Grundy SL, Reimer KJ (1995) Effect of local and distant contaminant sources: polychorinated biphenyls and other organochlorines in bottom-dwelling animals from the arctic estuary. Sci Total Environ 160/161: 265-283

Butler RB, Kelley ML, Powell WH, Hahn ME, Van Beneden RJ (2001) An aryl hydrocarbon receptor homologue from the soft-shell clam, Mya arenaria: evidence that invertebrate AHR lack TCDD and BNF binding. Gene 278:223-234

Chapman PM (1996) A test of sediment effects concentrations: DDT and PCB in the southern California bight. Environ Toxicol Chem 15:1197-1198

Chia FS, Xing J (1996) Echinoderm coelomocytes. Zool Stud $35: 231-254$

Chiu A, Chiu N, Beaubier J, Nalsnik R, Singh D, Hill WR, Lau C, Riebow J, (2000) Effects and mechanisms of PCB ecotoxicity in food chains: algae $\rightarrow$ fish $\rightarrow$ seal $\rightarrow$ polar bear. J Environ Sci Health Part C 18:127-152

Coteur G, Danis B, Fowler SW, Teyssié JL, Dubois Ph, Warnau M (2001) Effects of PCBs on reactive oxygen species (ROS) production by the immune cells of Paracentrotus lividus (Echinodermata). Mar Pollut Bull 42:667-672

Danis B, Cotret $\mathrm{O}$, Teyssié JL, Fowler SW, Bustamante $\mathrm{P}$, Warnau M (2003) Delineation of PCB uptake pathways in a benthic sea star using a radiolabelled congener. Mar Ecol Prog Ser 253:155-163

Danis B, Goriely S, Dubois P, Fowler SW, Flamand V, Warnau M (2004) Contrasting effects of coplanar vs non-coplanar PCB congeners on immunomodulation and CYP1A levels (determined using a novel ELISA method) in the common sea star Asterias rubens. Aquat Toxicol (Amst) 69: 371-384

den Besten PJ (1998) Cytochrome P450 monooxygenase system in echinoderms. Comp Biochem Physiol C 121: 139-146

den Besten PJ, Herwig HJ, Zandee DI, Voogt PA (1989) Effect of cadmium and PCBs on reproduction of the sea star Asterias rubens: aberration in the early development. Ecotoxicol Environ Saf 18:173-180

den Besten PJ, Herwig HJ, Van Donselaar EG, Livingstone DR (1990) Cytochrome P450 monooxygenase system and benzo(a)pyrene metabolism in echinoderms. Mar Biol 107: 171-177

den Besten PJ, Elenbaas JML, Maas JR, Dieleman SJ, Herwig HJ Voogt PA (1991) Effects of cadmium and polychlorinated biphenyls (Clophen A50) on steroid metabolism and cytochrome P-450 monooxygenase system in the sea star Asterias rubens L. Aquat Toxicol 20:95-110

den Besten PJ, Lemaire P, Livingstone DR, Woodin B, Stegeman JJ, Herwig HJ, Seinen W (1993) Time-course and dose-response of the apparent induction of the cytochrome P450 monooxygenase system of pyloric caeca microsomes of the female sea star Asterias rubens L. by benzo[a]pyrene and polychlorinated biphenyls. Aquat Toxicol (Amstd) 26:23-40

den Besten PJ, Valk S, van Weerlee E, Nolting RF, Postma JF, Everaarts JM (2001) Bioaccumulation and biomarkers in the sea star Asterias rubens (Echinodermata: Asteroidea): a North Sea field study. Mar Environ Res 51:365-387

Duffy JE, Carlson E, Li Y, Prophete C, Zelikoff JT (2002) Impact of polychlorobiphenyls (PCBs) on the immune function of fish: age as a variable determining adverse outcome. Mar Environ Res 54:559-563

Duncan DM, Burgess EA, Duncan I (1998) Control of distal antennal identity and tarsal development in Drosophila by spineless-aristapedia, a homolog of the mammalian dioxin receptor. Genes Dev 12:1290-1303

Everaarts JM, Sarkar A (1995) DNA damage as a biomarker of marine pollution: strand breaks in seastars (Asterias rubens) from the North Sea. Water Sci Technol 34:157-162

Everaarts JM, den Besten PJ, Hillebrand MTJ, Halbrook RS, Shugart LR (1998) DNA strand breaks, cytochrome P450dependent monooxygenase system activity and levels of chlorinated biphenyl congeners in the pyloric caeca of the seastar (Asterias rubens) from the North Sea. Ecotoxico$\operatorname{logy} 7: 69-79$

Fowler SW, Polikarpov GG, Elder DL, Parsi P, Villeneuve JP (1978) Polychlorinated biphenyls: accumulation from contaminated sediments and water by the polychaete Nereis diversicolor. Mar Biol 48:303-309

Hahn ME (1998) The aryl hydrocarbon receptor: a comparative perspective. Comp Biochem Physiol C 121:23-53

Hahn ME, Karchner SI, Shapiro MA, Perera SA (1997) Molecular evolution of two vertebrate aryl hydrocarbon (dioxin) receptors (AHR1 and AHR2) and the PAS family. Proc Natl Acad Sci USA 94:13743-13748

Harding GC, Addison RF (1986) Accumulation and effects of 
PCBs in marine invertebrates and vertebrates. In: Wood JS (ed) PCBs and the environment, Vol II. CRC Press, Boca Raton, FL, p 9-30

Kohn HW (1983) The significance of DNA damage assays and carcinogenecity assessment. Ann NY Acad Sci 407: 106-118

Koponen K, Kukkonen JVK, Lindstrom-Seppa P (1998) Chemical accumulation and biotransformation enzyme acitvities of rainbow trout embryos in waterborne exposure to PCB77. Mar Environ Res 46:475-478

Krogenaes AK, Nafstad I, Skare JU, Farstad W, Hafne AL (1998) In vitro reproductive toxicity of polychlorinated biphenyl congener 153 and 126. Reprod Toxicol 12: 575-580

Livingstone DR, Chipman JK, Lowe DM, Minier C, Mitchelmore CL, Moore MN, Peters LD, Pipe RK (2000) Development of biomarkers to detect the effects of organic pollution on aquatic invertebrates: recent molecular, genotoxic, cellular and immunological studies on the common mussel (Mytilus edulis L.) and other mytilids. Int J Environ Pollut 13:56-91

McCarthy JF, Shugart LR (eds) (1990) Biomarkers of environmental contamination. Lewis Publishers, Boca Raton, FL

Metcalfe CD (1994) Polychlorinated biphenyls. In: Kiceniuk JW, Ray S (eds) Analysis of contaminants in edible aquatic resources. VCH Press, Berlin, p 305-338

Michel XR, Suteau P, Robertson LW, Narbonne JF (1993) Effects of benzo(a)pyrene, 3,3',4,4'-tetrachlorobiphenyl and $2,2^{\prime}, 4,4^{\prime}, 5,5^{\prime}$-hexachlorobiphenyl on the xenobiotic metabolizing enzymes in the mussel (Mytilus galloprovincialis). Aquat Toxicol 27:335-344

Murdoch MH, Chapman PM, Norman DM, Quintino VM (1997) Spiking sediment with organochlorines for toxicity testing. Environ Toxicol Chem 16:1504-1509

Nebert DW, Matthew ALR, Dieter Z, Solis WA, Yang Y, Dalton TP (2000) Role of the aromatic hydrocarbon receptor and $[A h]$ gene battery in the oxidative stress response, cell cycle control, and apoptosis. Biochem Pharmacol 59:65-85

OSPAR Com (Oslo-Paris Commission) for the Protection of the Marine Environment of the North-East Atlantic (2000) Quality Status Report for the North-East Atlantic. OSPAR Commission, London

Peakall D (ed) (1992) Animal biomarkers as pollution indicators. Ecotoxicology Series 1. Chapman \& Hall, London

Powell-Coffman JA, Bradfield CA, Wood WB (1998) Caenorhabditis elegans orthologs of the aryl hydrocarbon receptor and its heterodimerisation partner the aryl hydrocarbon receptor nuclear translocator. Proc Natl Acad Sci USA 95:2844-2849

Safe S (1995) Modulation of gene expression and endocrine response pathways by 2378-tetrachlorodibenzo-p-dioxin and related compounds. Pharmacol Ther 67:247-281

Satar AA (2000) The immune system as a potential target for environmental estrogens (endocrine disrupters): a new emerging field. Toxicology 150:191-206

Schreitmüller J, Vigneron M, Bacher R, Ballschmiter K (1994) Pattern analysis of polychlorinated biphenyls (PCBs) in marine air of the Atlantic Ocean. Int J Environ Anal Chem $57: 33-52$

Schweitzer LE, Hose JE, Suffet IH, Bay SM (1997) Differential toxicity of three PCB congeners in developing sea urchin embryos. Environ Toxicol Chem 16:1510-1514

Editorial responsibility: Otto Kinne (Editor),

Oldendorf/Luhe, Germany
Shugart LR, Bickham J, Jackim G, McMahon G, Ridley W, Stein J, Steinert S (1992) DNA alterations. In: Huggett RJ, Kimerle RA, Mehrle PM, Bergman HL (eds) Biomarkers: biochemical, physiological and histological markers of anthropogenic stress. Lewis Publishers, Chelsea, MI, p 125-163

Stebbing ARD, Dethlefsen V, Carr M (1992) Biological effects of contaminants in the North Sea. Mar Ecol Prog Ser 91 (MEPS Special)

Stegeman JJ, Hahn ME (1994) Biochemistry and molecular biology of monooxygenases: current perspectives on forms, functions, and regulation of cytochrome P450 in aquatic species. In: Ostrander GK, Malins D (eds) Aquatic toxicology: molecular, biochemical and cellular perspectives. Lewis Publishers, Boca Raton, FL, p 87-95

Stegeman JJ, Brouwer M, DiGiulio RT, Forlin L, Fowler BM, Sanders BM, Van Veld PA (1992) Molecular responses to environmental contamination: enzyme and protein systems as indicators of contaminant exposure and effect. In: Huggett RJ (ed) Biomarkers for chemical contaminants. CRC Press, Boca Raton, FL, p 87-206

Stronkhorst J, Ariese F, van Hattum B, Postma JF and 6 others (2003) Environmental impact and recovery at two dumping sites for dredged material in the North Sea. Environ Pollut 124:17-31

Suedel BC, Dillon TM, Benson WH (1997) Subchronic effects of five di-ortho PCB congeners on survival growth and reproduction in the fathead minnow Pimephales promelas. Environ Toxicol Chem 16:1526-1532

Suter GW (1993) Ecological risk assessment. Lewis Publishers, Boca Raton, FL

Tolosa I, Readman JW, Fowler SW, Villeneuve JP, Dachs J, Bayona JM, Albaiges J (1997) PCBs in the western Mediterranean: temporal trends and mass balance assessment. Deep-Sea Res 44:907-928

UNEP (United Nations Environment Program, IOC/IAEA/FAO) (1990) Reference method no 57: contaminant monitoring programs using marine organisms: quality assurance and good laboratory practice. UNEP, Vienna

Wania F, Daly GL (2002) Estimating the contribution of degradation in air and deposition to the deep sea to the global loss of PCBs. Atmos Environ 36:5581-5593

Whicker FW, Schultz V (1982) Radioecology: nuclear energy and the environment, Vol 2. CRC Press, Boca Raton, FL

Wiesner L, Powell WH, Karchner SI, Franks DG, Cooper EL, Kauschke E, Hahn ME (2001) cDNA cloning of aryl hydrocarbon receptor (AhR) homologues in zebra mussel (Dreissena polymorpha) and blue mussel (Mytilus edulis). In: Jones MB (ed) Pollutant responses in marine organisms (PRIMO 11). Plymouth

Wilbrink $M$, Treskes $M$, De Vlieger TA, Vermenlen NPE (1991) Comparative toxicokinetics of 2,2'- and 4,4'dichlorobiphenyls in the pond snail Lymnea stagnalis (L.). Arch Environ Contam Toxicol 19:565-571 320

Wilkinson L (1988) SYSTAT: the system for statistics. SYSTAT Evanston, IL

Zabel AW, Cook PM, Peterson RE (1995) Toxic equivalency factors of PCDD, PCDF, and PCB congeners based on early life stage mortality in rainbow trout (Oncorhynchus mykiss). Aquat Toxicol 31:315-328

Zar JH (1996) Biostatistical analysis, 3rd edn. Prentice-Hall, Upper Saddle River, NJ

Submitted: January 27; 2004 Accepted: April 20, 2004

Proofs received from author(s): September 14, 2004 